Óscar LUENG $\quad$ DOI : 10.14746/pp.2017.22.3.2

Universidad de Granada, ${ }^{2}$ Spain

\title{
Political Participation and New Technologies of Communication in Spain
}

\begin{abstract}
The consolidation of the Internet as not only a media outlet, but also a multifunctional platform, has put into question the traditional relationship between media and political participation. The latest political developments in Spain, such as the 15-M movement or the success of Podemos, show that new technologies increase the options for new and fresh ways of political activism. This study provides a diagnosis of the role played by new technologies of communication, particularly the Internet, in political activism in Spain. The results show a noteworthy dissemination of the Internet as a political information source, as well as a platform to participate in politics. In addition, the analysis suggests that online participation is a phenomenon more popular among young people, with high studies and located on the ideological left. This profile is similar to that of citizens who support the new political forces like Podemos and the different citizens' movements which are demanding a reconfiguration of the democratic system in Spain.
\end{abstract}

Key words: Internet, new technologies, media, political activism, e-activism

\section{Introduction}

n recent years, Spain has been configured as an important reference in the study of new forms of social participation and political activism. The first significant recent event was the demonstrations on $13^{\text {th }}$ March, 2004, taking place after the terrorist attacks in Madrid and three days before general parliamentary elections. The episode represented an interesting challenge for political communication research, since the call was organised via cell phones (short message services - SMS). Seven years later, taking advantage of the upcoming local elections, a group of activists called for social action on $15^{\text {th }}$ May, 2011. With no institutions involved and without formal leadership, the announcement quickly spread around social networks and thousands of people were mobilised in 50 Spanish cities, with the most significant example in Puerta del Sol (Madrid). Similar movements were replicated in more than 100 Spanish cities, and in a few days all of them were operating in unison, discussing quite varied issues concerning the collective worries surrounding the outrage, within articulated public, open committees and assemblies. Moreover, this dynamic reached over 800 cities in the world (Castells, 2012, p. 118). This multifaceted and complex phenomenon soon acquired its own identity under the name of $15-\mathrm{M}$ (the date of the first demonstration, $15^{\text {th }}$ May, 2011), and soon after it was labelled the "Outraged Movement"" following the very successful tag proposed by Hessel (2011).

\footnotetext{
${ }^{1}$ We would like to thank Marta Przywara for her assistance in the translation of the abstract to Polish.

2 Rector López Argüeta, s/n. 18071 Granada (Spain), ogluengo@ugr.es; bfgarcia@ugr.es.

${ }^{3}$ Movimiento Indignados.
} 
Those new forms of political participation share a common feature: most of them were born and grounded in social networking. Therefore, 15-M saw a major contribution to the study of new social and political mobilisation. It promoted the creation of a group of people predisposed to social activism under the wide umbrella of concerns about the economic and political crises. These movements have been encouraged by the boom of new information and communication technologies (ICT), in particular the spread of the Smartphone, and a new sense of social awareness and collective sense perception (Luengo, Marín, 2016).

Whilst some social movement scholars were already focussing on the Internet and its role before the 2011 protest movements, informal groups have been neglected in the literature in contrast to political parties and traditional players (Van de Donk, Loader, Nixon, Rucht, 2004, p. 2). Cyberactivism, or online participation has been the main scope of research of very few studies (Bennett, 2003; van de Donk et al., 2004). The extra-parliamentarian area was identified as a realm where ICT play a more significant role, "even enabling forms of participation that would not have been possible without them" (Dahlgren, 2004, p. xiii). Therefore, the Internet helps to promote alternative or counter public spheres that can offer a new, empowering sense of what it means to be a citizen.

The Internet helps to articulate and mobilise different individuals by affinities, loyalties and compromises. The Web 2.0 has an impressive potential: the democratisation and decentralisation of big social movements. The usage of social networks and the Internet have made it possible for significant geographic areas to organise in a non-hierarchical way (Petray, 2011, p. 936).

Hence, the nature of social movements and political participation in Spain changed after the collapse of the economy a few years ago. Nonetheless, this is not only provoked by economic factors; it also has to do with the lack of confidence in traditional political institutions, and the distrust towards representative organisations and the mass media. Consequently, these important events inspired and framed notions of unfair societies, inequality, poverty and a lack of effective democracy (Luengo, Marín, 2016, p. 58).

The increasing use of new technologies of information and communication has changed the very essence of the political process in general, and social and political mobilisation in particular. As a consequence of the facts already described, we can observe in Spain interesting examples of these new dynamics: the emergence of Podemos, at the moment the third political party that has obtained power in the biggest Spanish cities (Barcelona and Madrid), rooted in the outrage movement; the organisation of new platforms that involve new ways of participation fostering the online participation of citizens, for example appgree ${ }^{4}$ or the Madrid city-hall online space. ${ }^{5}$

Whilst some scholars have highlighted the increase of political disaffection over the last decades, the truth is that in this new environment more and more citizens are taking part in the political process through very varied and fresh ways of participation.

Hence, the scope of this chapter has to do with the diagnosis of the role played by new technologies of communication, particularly the Internet, in political and social activism in Spain, understanding this concept as one dimension of political participation.

\footnotetext{
${ }^{4}$ Appgree is a web and phone application, able to find the ideas most supported by an unlimited number of people. With Appgree, any community can express itself quickly and easily (https://www. appgree.com).

${ }^{5}$ https://decide.madrid.es/.
} 


\section{Theoretical framework}

Many political scientists have traditionally underlined the fact that political disaffection has continuously increased in past decades. Scholars have focused their efforts in understanding the complex developments through which we have arrived at a particular pattern of conduct that could be broadly characterised by the combination of, on the one hand, low levels of electoral turnout, political participation and activism, political efficacy, political knowledge and political understanding, and, on the other hand, the firm approval of democratic principles. This dynamic has been pointed out as a potential component of the instability of the political system (Luengo, 2005, p. 59).

Social sciences in general, and political and media sciences specifically, have explored the causes of these behavioural patterns and have developed a theoretical framework to face this challenging phenomenon. The belief that the processes of political communication have substantially altered the political and civic engagement of citizens in one way or another, has become a constant conviction among scholars and journalists, especially in the North American context (Luengo, Maurer, 2009), emphasising the potential implication of media coverage in fostering those patterns of political culture.

The development of political communication as a discipline suggests some contrasting explanations around the relationship between the mass media and political engagement. On the one hand, we find some authors that accuse the media of "narcotising" the citizens, who are increasingly less participative and less trusting of political institutions, and are, in the terms of Robert Putnam, disaffected democrats (Robinson, 1976; Patterson, 1994; Fallows, 1996; Cappella, Jamieson, 1997; Putnam, Pharr, 2000; Putnam, 2000). On the other hand, some recent analyses state that the empirical evidence points in the opposite direction (Holtz-Bacha, 1990; Newton, 1999; Norris, 2000).

\section{Theories of Media Malaise ${ }^{6}$}

In 1976, Michael Robinson popularised the term videomalaise, arguing that television as a source of political information causes political disaffection. In order to explain the growth of what he called videomalaise, the author pointed out six interrelated factors: 1) the anomalous magnitude and shape of television news audiences, 2) the public perceptions of the credibility of networks, 3) the interpretative character of television news coverage, 4) the stress on negative elements of television news reports, 5) the emphasis on conflict and violence in network reporting, and 6) the anti-institutional theme of news programs on television (Robinson, 1976, p. 426). All these elements came together to promote political disaffection, frustration, cynicism and malaise in the general public.

This perspective made special sense in the North American political context. Television news in the U.S. does, indeed, present political life in a more negative way than newspapers do (Robinson, Sheehan, 1983). Political disaffection in the U.S. increases parallel to the increase in negative news stories about politicians and political institutions in the American media (Lichter, Amundson, 1994; Patterson, 1993). In summary, the theories of media

\footnotetext{
${ }^{6}$ This theoretical discussion can be followed in more depth in Luengo, 2005; Luengo, 2012.
} 
malaise maintain two central assumptions: 1) the processes of political communication via mass media have a significant impact on the civic engagement of the citizens; 2) this impact heads in a negative direction or, in other words, the lack of social commitment towards the political process is determined by the process of political communication (Luengo, 2005).

\section{Theories of Political Mobilisation}

The theoretical proposal presented above is challenged by a set of scientific works, the results of which have been grouped under the label of theories of political mobilisation. Despite the fact that these new interpretations do not fully eliminate all the previous contributions, they add substantial nuances to the main videomalaise concerns. In other words, they suggest that the contemporary mass media have a significant impact on citizens - this point is shared with the media malaise position - but this influence is produced in a positive direction, maintaining and promoting political commitment and, hence, democratic participation.

The theories of political mobilisation appeared on the academic scene with great influence in the nineties (Holtz-Bacha, 1990; Norris, 1996; Newton, 1999; Norris, 2000), with the diffusion of some pieces of research work. We could state that the first analyses along this line arose as a result of the contrast with the media malaise hypotheses. Somehow, this explanation considers that including differences in some analytical categories, media malaise theories are not strictly applicable as they were formulated. Essentially, mobilisation theories underline that "we need carefully to disentangle the positive and negative effects of different media, messages, audiences and effects" (Norris et al., 1999, p. 99). In this sense, for example, the group of regular consumers of television news and habitual readers of the political press are - regardless of tone of media coverage - more inclined to be informed, participative, interested and committed to political life. On the contrary, citizens exposed to sensationalist content usually present levels of political disaffection, cynicism and alienation.

Finally, it is vital to mention the importance of a theory that, although framed within the theories of the mobilisation, acquires a special status, since its considerations entail significant advances with respect to the general assumptions - the theory of the Virtuous Circle (Norris, 2000). In spite of proposing a similar perspective to the contributions of the theory of political mobilisation and objecting to the conclusions of media malaise, the theory of the virtuous circle, stated by Pippa Norris, goes one step further and provides a more complete theoretical elaboration. As a result of the examination of empirical evidence derived from data analysis of the United States and Western Europe, one of the main assumptions of this theory resides in the following statement: the attention to the news in general is not configured as a factor that contributes to the erosion of support for the political system. On the contrary, those consistently exposed to news and electoral campaigns are revealed as the most knowledgeable in political terms, as most trusting of the government and the political system, and as the most participative (Luengo, 2005).

Nevertheless, it seems that the latest developments have challenged the traditional concept of political disaffection as a generalised trend in the political culture of the contemporary Western world. In the last decade, citizens in some countries, like Spain, are becoming 
more and more politically active. The consolidation of the Internet as not only a media outlet, but also a multifunctional platform, has put into question the traditional relationship between the media and political participation. We have observed a profound alteration regarding what was pointed out by the media malaise theorists. The development of new media outlets, which is clearly a process, not an exclusive and isolated event, has extended the possibilities of study. We are pointing not only at the Internet itself, but also at the enormous potentiality found in social media, including Facebook and Twitter, among others.

\section{Methodology}

The aim of this study is the analysis of new means of political activism in Spain and its relationship with exposure to media content. In order to achieve this goal, we are going to run a quantitative analysis to get an approximation of the e-activist profile. Our data set comes from study no. 3126 of the Sociological Research Centre (Centro de Investigaciones Sociológicas - CIS), a wide post-electoral survey of the latest Spanish Parliamentary elections. The total sample size of the survey is 6,242 interviews.

\section{Dependent variable}

Participation in political forums or discussions online was used to measure the new means of political activism on the Internet. Other questions about political activism are presented in the results to get an approximation of the dissemination of political activism on the Internet compared to other more traditional means of political activism.

The original question ${ }^{7}$ for our dependent variable was presented in the questionnaire as follows:

"P. 16. Please tell me if you have done the following actions that people carry out to state their opinion about a problem... P. 16.4.: Participate in a political forum or discussion online...: 1) On many occasions; 2) Once in a while; 3) Never; 9) Don't know."

In order to run the logistic regression, the dependent variable was recoded as follows: 1. Yes (categories 1 and 2); 0. No (category 3).

\section{Independent variables}

The survey includes questions on respondent exposure to media content, making a distinction between newspapers, TV and radio. The questions were: ${ }^{8}$

${ }^{7}$ P.16. Me gustaría que me dijera si ha realizado en bastantes ocasiones, alguna vez o nunca, las siguientes acciones que la gente lleva a cabo para dar a conocer su opinión sobre algún problema... 16.5.: Participar en un foro o grupo de discusión política en Internet.... 1) En bastantes ocasiones; 2) Alguna vez; 3) Nunca; 9) NC (original version in Spanish).

${ }^{8}$ P.19.1. Durante esta campaña electoral, ¿con qué frecuencia ha seguido Ud. La información politica y electoral a través de los periódicos de información general? ¿Y a través de la televisión? 
"P.19.1. During this electoral campaign, how often have you followed the political and electoral information in the newspapers? And on TV? And on the radio? 1) Every day or almost every day; 2) Four or five times a week; 3) Two or three times a week; 4) Only on weekends; 5) Never or almost never; 9) Don't know."

In order to get a political profile, we also included trust in the national parliament ${ }^{9}$ and the ideological self-location ${ }^{10}$ as independent variables. In addition, the multivariate analysis was controlled by the traditional socio-demographic variables: gender, age and education.

\section{Results}

Political activism and exposure to media content in Spain

Table 1 shows that political activism on the Internet is still less generalised among Spanish people than other types of actions, such as taking part in public demonstrations, boycotting certain products for political reasons or participating in strikes. Nearly 90 percent of the respondents have never participated in a political forum or discussion online, in contrast with the other three means of activism: between 42-49 percent of respondents have participated at some point in public demonstrations, strikes or have stopped buying certain products for political reasons. The least common political actions are the occupation of buildings and blocking traffic: 92.1 percent of respondents have never participated in this kind of protest.

Table 1

Types of political activism

\begin{tabular}{|l|c|c|c|}
\hline \multicolumn{1}{|c|}{$\mathbf{N = \mathbf { 6 2 4 2 }}$} & $\begin{array}{c}\text { On many } \\
\text { occasions } \\
\mathbf{( \% )}\end{array}$ & $\begin{array}{c}\text { Once in } \\
\text { a while } \\
\mathbf{( \% )}\end{array}$ & $\begin{array}{c}\text { Never } \\
\mathbf{( \% )}\end{array}$ \\
\hline Take part in a lawful public demonstration & 12.1 & 37.3 & 50.3 \\
\hline Boycott certain products for environmental, political or moral reasons & 10.8 & 29.8 & 58.4 \\
\hline Participate in a strike & 8.4 & 33.5 & 57.7 \\
\hline Occupy buildings or block traffic & 0.9 & 5.5 & 92.1 \\
\hline Participate in a political forum or discussion online & 2.7 & 7.4 & 89.3 \\
\hline
\end{tabular}

Source: CIS no. 3126 (January, 2016).

¿Y a través de la radio? 1) Todos o casi todos los días; 2) Cuatro o cinco días por semana; 3) Dos o tres días por semana; 4) Sólo los fines de semana; 5) De vez en cuando; 6) Nunca o casi nunca; 7) N.C. (original version in Spanish).

9 "P. 6: Please tell me on a score of $0-10$ how much you personally trust each of the institutions I read out. 0 means you do not trust an institution at all, and 10 means you have complete trust. 6.1.: The national parliament."

10 'P. 35: In politics people sometimes talk of 'left' and 'right'. Using this card, where would you place yourself on this scale, where 1 means the left and 10 means the right?" 
Regarding the exposure to media content, Table 2 shows that TV is the most popular media outlet in Spain: 58.5 percent of respondents followed the electoral and political information on TV every day or almost every day, in contrast to 23.1 percent of respondents who followed the electoral information daily in the newspapers or 19.8 percent who did so on the radio, respectively. On the other hand, it is especially interesting to notice how common it has become for people to use the Internet as a source of political information in electoral campaigns. As Table 3 shows, 76.4 percent of respondents followed the electoral information on the Internet at some point. Digital media ( 32.4 percent) and social media (20.8 percent) were the most popular websites for following electoral information during the campaign of December.

Table 2

During this campaign, how often have you followed the electoral/political information...?

\begin{tabular}{|l|c|c|c|}
\hline \multicolumn{1}{|c|}{$\mathbf{N}=\mathbf{6 2 4 2}$} & In the newspapers (\%) & On TV (\%) & On the radio (\%) \\
\hline Every day or almost every day & 23.1 & 58.5 & 19.8 \\
\hline Four or five times a week & 4.4 & 10.1 & 3.4 \\
\hline Two or three times a week & 6.1 & 7.7 & 3.9 \\
\hline Only weekends & 3.3 & 1.6 & 0.9 \\
\hline Once in a while & 8.5 & 9.2 & 7.6 \\
\hline Never or almost never & 54.5 & 12.9 & 64.4 \\
\hline
\end{tabular}

Source: CIS no. 3126 (January, 2016).

Table 3

Following the electoral/political information on the Internet (\%)

\begin{tabular}{|l|c|c||}
\hline \multicolumn{1}{|c|}{ Types of online source } & Frequency abs. & \% (over the total N) \\
\hline Digital media & 2022 & 32.4 \\
\hline Websites of political parties or candidates & 426 & 6.8 \\
\hline Websites of citizen organisations or civic movements & 261 & 4.2 \\
\hline Blogs and discussion forums & 357 & 5.7 \\
\hline Social media & 1301 & 20.8 \\
\hline Other websites & 405 & 6.5 \\
\hline Total & $4770(76.4 \%)$ & $\mathrm{N}=6242$ \\
\hline
\end{tabular}

Source: CIS no. 3126 (January, 2016).

\section{The "e-activist" profile}

The aim of this chapter is to get a profile of the political activist on the Internet, and to analyse its relationship with exposure to media content. The regression analysis that is presented in Table 4 shows an approximation of this profile: younger respondents, with higher levels of education, and who are located on the ideological left are more likely to participate in political forums or discussions online. Gender and trust in the national parliament do not maintain a significant relation with the dependent variable. However, it is interesting that the direction of the relation between trust and political activism on 
the Internet is negative. In other words, the more distrustful respondents are, the more likely they are to participate in this kind of online discussion.

On the other hand, the results suggest that the respondents that follow political information in the newspapers and on the radio are more likely to participate than the respondents that watch $\mathrm{TV}$.

Table 4

The "e-activist" profile.

Logistic Regression results

\begin{tabular}{|l|c|c|c|}
\hline & B & $\mathbf{E x p ( B )}$ & Error std. \\
\hline Age &,- 033 & $0,967^{* * *}$ &, 003 \\
\hline Gender $(1=$ male) &, 117 & 1,124 &, 096 \\
\hline Education &, 346 & $1,414^{* * *}$ &, 040 \\
\hline Ideology &,- 214 & $0,808^{* * *}$ &, 027 \\
\hline Trust on national parliament &,- 008 &, 992 &, 021 \\
\hline Newspapers &, 248 & $1,281^{* * *}$ &, 025 \\
\hline TV &,- 070 & $0,933^{*}$ &, 029 \\
\hline Radio &, 082 & $1,085^{* * *}$ &, 023 \\
\hline Constant & $-1,958$ & $0,141^{* * *}$ &, 289 \\
\hline $\mathrm{R}^{2}$ Nagelkerke $(\%)$ & \multicolumn{3}{|l}{$21.6^{* * *}$} \\
\hline
\end{tabular}

D. V.: Participation in a political forum or discussion on the Internet (1: Yes; 0: No).

$\mathrm{N}$ total $=6242(\mathrm{~N}$ included in the analysis $=5043)$.

$*>0.05 * *<0.01 * * * 0.001$.

Source: CIS no. 3126 (January, 2016).

\section{Conclusions}

The latest political developments in some countries, like Spain, lead us to question the concept of political disaffection as a generalised trend in the political culture of the contemporary Western world. In recent years, we have witnessed the emergence of new and fresh means of political activism in Spain, such as the 15-M Movement, in which social media played an important role, or the emergence of Podemos, in which the online participation of its supporters was crucial. New technologies have played a central role in these new political developments inasmuch as they are a tool that allows new, and less hierarchical ways of political participation.

This study provides a diagnosis of the role played by new technologies of communication, particularly the Internet, in political activism in Spain. Our theoretical framework suggests that the different processes of political communication have substantially altered the citizen's political and civic engagement.

First, we observed that political activism on the Internet is still a minority phenomenon in comparison with other means of political activism, such as the participation in public demonstrations or strikes. Nevertheless, a noteworthy 10.1 percent of the respondents participated at some point in political forums or discussions online. On the other hand, we found a strong dissemination of the Internet as a source of political information in the campaign period of 2015: more than 76 percent followed the electoral and 
political information at some point through different websites, especially from digital media and social media.

Second, we analysed the e-activist profile and the relationship between exposure to media content and online activism. The results suggest that online participation is a phenomenon more popular among young people with higher education and located on the ideological left. Surprisingly, we found that people that trust political institutions are less likely to participate in political discussions on the Internet (although this relationship was not stastically significant). This profile is similar to that of citizens who support the new political forces like Podemos and the different citizens' movements (the "Mareas ciudadanas"), who demand a reconfiguration of the democratic system in Spain. Despite high unemployment and growing social inequality following the economic crisis of 2008, the political protests in Spain have largely focused on the quality of democracy, demanding more transparency in political processes, more democracy within political parties and a less hierarchical relationship between the rulers and the ruled.

Regarding the relation between exposure to media content and political activism, several studies have addressed this topic and have reached different results. Following the so-called media malaise theories, the exposure to negative media content is related to political disaffection and political cynicism. In contrast, media mobilisation theories have shown that exposure to media content leads to well-informed and mobilised citizens. Our results are in line with political mobilisation theories (Holtz-Bacha, 1990; Norris, 1996; Newton, 1999; Norris, 2000) in the cases of exposure to newspapers and the radio: respondents who followed electoral and political information in the newspapers and on the radio are more likely to participate in political forums and discussions online, even controlling for age, gender and education. On the other hand, the logistic regression showed that exposure to TV and political activism on the Internet are negatively related. Some scholars have pointed out that television news presents political information in a more negative way than newspapers (Robinson, Sheehan, 1983). This could have a negative effect on political engagement. Taken together, these results suggest the possibility of different effects on political activism as a result of the exposure to news on different outlets.

To sum up, the consolidation of the Internet has extended the possibilities for new and fresh means of political activism, as well as the development of new sources of political information. That could have a positive effect on the political engagement of new generations that demand more transparency and civic participation within the political system.

\section{Bibliography}

Bennett L. W. (2003), Communicating Global Activism. Information, "Communication \& Society", vol. 6, no. 2, pp. 143-266.

Cappella J., Jamieson C. (1997), Spiral of Cynicism: The Press and the Public Good, Oxford University Press, New York.

Castells M. (2012), Redes de Indignación y Esperanza, Alianza, Madrid.

Dahlgren P. (2004), Foreword, in: W. Van de Donk, B. Loader, P. Nixon, D. Rucht, Cyberprotest: New Media, Citizens and Social Movements, Routledge, London, pp. 6-17. 
Dimitrova D., Shehata J., Strömback J., Nord L. W. (2014), The effects of digital media on political knowledge and participation in election campaigns: evidence from panel data, "Communication Research", vol. 41, no. 1, pp. 95-118.

Easton D. (1965), A systems analysis of political life, Wiley, New York.

Fallows J. (1996), Breaking the News: How the Media Undermine American Democracy, Pantheon, New York.

Hessel S. (2011), ;Indignaos! Un alegato contra la indiferencia y a favor de la insurrección pacifica, Destino, Madrid.

Holtz-Bacha C. (1990), Videomalaise Revisited: Media Exposure and Political Alienation in West Germany, "European Journal of Communication", no. 5, pp. 73-85.

Lichter R. S., Amundson D. R. (1994), Less News is Worse News: Television Coverage of Congress, 1972-1992. in: Congress, the Press, and the Public, eds. T. E. Mann, N. J. Ornstein, Brookings Institution Press, Washington, pp. 131-140.

Luengo O. (2005), Media Malaise Revisited: Media Exposure and Political Activism in Europe, "Central European Political Science Review", vol. 6, no. 19, pp. 72-88.

Luengo O. (2012), Internet y nuevos repertorios de acción colectiva en Europa. ¿Invalida el 15M el malestar mediático?, in: Ciberpolítica. Las nuevas formas de acción y comunicación políticas, ed. R. Cotarelo, Tirant Lo Blanch, Valencia, pp. 257-278.

Luengo O., Maurer M. (2009), A Virtuous Circle for All? Media Exposure and Political Trust in Europe, "CONfines", no. 5/9, pp. 39-48.

Luengo O., Marín J. (2016), Communication Strategies and New Political Movements, in: Beyond the Internet; Unplugging the Protest Movement Wave, eds. R. Figueiras, P. Espirito Santo, Routledge, London, pp. 53-75.

Newton K. (1999), Mass Media Effects: Mobilisation or Media Malaise, "British Journal of Political Science", no. 29, pp. 577-599.

Norris P. (1996), Does Television Erode Social Capital? A Reply to Putnam, "Political Science and Politics", vol. 29, no. 3, pp. 474-480.

Norris P. (1999), Introduction: The Growth of Critical Citizens?, in: Critical Citizens: Global Support for Democratic Government, ed. P. Norris, Oxford University Press, Oxford, pp. 1-27.

Norris P. (2000), A Virtuous Circle: Political Communication in Postindustrial Societies, Cambridge University Press, New York.

Patterson T. (1993), Out of Order, Knopf, New York.

Petray T. L. (2011), Protest 2.0: online interactions and Aboriginal activists, "Media Culture Society", vol. 33, no. 6, pp. 923-940.

Putnam R. D. (2000), Bowling Alone, Simon \& Schuster, New York.

Putnam R. D., Pharr S. J., Dalton R. J. (2000), Introduction: What's Troubling the Trilateral Democracies, in: Disaffected Democrats: What's Troubling the Trilateral Democracies, eds. R. D. Putnam, S. J. Pharr, Princeton University Press, Princeton, pp. 3-27.

Robinson M. (1976), Public affairs television and the growth of political malaise: The case of The Selling the Pentagon, "American Political Science Review", no. 70, pp. 409-432.

Robinson M., Sheehan M. A. (1983), Over the Wire and on TV. CBS and UPI in Campaign '80, Russell Sage Foundation, New York.

Van De Donk W., Loader B. D., Nixon P. G., Rucht D. (2004), Cyberprotest: New media, citizens and social movements, Routledge, London-New York.

Yamamoto M., Kushin M. (2014), More harm than Good? Online media use and political disaffection among college students in the 2008 election, "Journal of Computer-Mediated Communication", no. 19 , pp. $430-445$.

Zhang W., Johnson T. J., Bichard S. L. (2010), The Revolution Will be Networked The Influence of Social Networking Sites on Political Attitudes and Behaviour, "Social Science Computer Review", vol. 28, no. 1, pp. 75-92. 


\section{Partycypacja polityczna i nowe technologie komunikacyjne w Hiszpanii}

\section{Streszczenie}

Konsolidacja Internetu będącego nie tylko medium, ale także wielofunkcyjną platformą, podważyła tradycyjne relacje między mediami a partycypacją polityczną. Najnowsze wydarzenia polityczne w Hiszpanii, takie jak ruch 15-M czy sukces partii Podemos pokazuja, że nowe technologie zwiększają możliwości nowych i nowatorskich sposobów aktywności politycznej. Niniejszy artykuł stanowi diagnozę roli, jaką odgrywają nowe technologie komunikacyjne, w szczególności Internet, w działalności politycznej w Hiszpanii. Wyniki pokazują godne uwagi upowszechnienie Internetu jako źródła informacji politycznych, a także jako platformy partycypacji politycznej. Analiza sugeruje ponadto, że partycypacja w sieci jest zjawiskiem bardziej popularnym wśród młodych ludzi z wykształceniem wyższym i mających poglądy lewicowe. Profil ten jest zbliżony do charakterystyki obywateli, którzy wspierają nowe siły polityczne, takie jak Podemos i różne ruchy obywatelskie domagające się przebudowy systemu demokratycznego w Hiszpanii.

Słowa kluczowe: Internet, nowe technologie, media, aktywność polityczna, e-aktywność 
